\title{
Benefits and Consequences of Diversification: Evidence from Financialzed Commodity Portfolios
}

\author{
Rangga Handika ${ }^{1 \rtimes}$ \\ Mahjus Ekananda ${ }^{2}$
}

'Institute for International Strategy, Tokyo International University, Japan. Email:rhandikapro@yahoo.com

${ }^{2}$ Department of Economics, Faculty of Economics and Business, University of Indonesia, Indonesia.

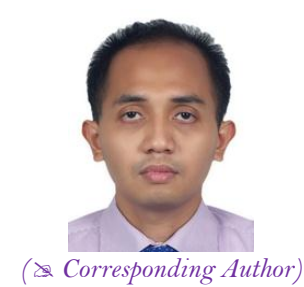

Theck for updates

\begin{abstract}
The financial risk analysis of commodity markets has become an increasingly important issue in the recent decade. However, studies about commodities portfolio diversification benefits are limited. An analysis of commodities as a portfolio (rather than a single asset) should generate more interest from investors since the portfolio enhances single asset due to diversification benefit. This paper investigates the diversification benefits and consequences of portfolio in financialized commodity markets. Using eight financialized commodities at different data frequencies (daily, weekly and monthly) to construct seven equally weighted portfolios, we calculate portfolios valueat-risk (VaR) and expected shortfall (ES). Then, we perform back testing at 99 percent, 95 percent and 90 percent VaR levels. We find that on average commodities portfolios tend to have less accurate VaR and higher number of returns that are lower than ES. We conclude that even though portfolios have diversification benefits such as reducing risk and capital requirements, there are also unintended consequences.
\end{abstract}

Keywords: Commodity markets, Portfolio, Diversification, Value-at-risk, Expected shortfall, Back-testing

JEL Classification: G1 1; G17; G31; Q02; Q40.

\section{Contribution of this paper to the literature}

This paper contributes to the literature in twofold. First, this paper extends further previous research on commodity volatility modeling by considering commodity portfolio volatility rather than single commodity volatility. Second, it offers new perspective of investigating portfolio VaR and ES in commodity markets.

\section{Introduction}

The financial risk analysis of commodity markets has become an increasingly important issue in the recent decade. One of the reasons is that a dramatic increase in the investments of commodity markets (Basak and Pavlova, 2016). They realize huge price increases and prices fluctuations in the commodity markets. Another paper by Casassus and Dufresne (2005) also documents a tremendous growth in commodity derivatives markets. Specifically, according to Daskalaki and Skiadopoulos (2011) there is a $\$ 9$ billion increase in commodity investments from 2006 to 2009.

Furthermore, Irwin and Sanders (2011) note that there are more than $\$ 100$ billion invested from 2004 to 2008 in the commodity futures markets. Basu and Miffre (2013) also reports that there is a huge increase from $\$ 18$ billion in 2003 to $\$ 250$ billion in 2010 for commodities institutional investments.

Overall, we can conclude that there are more investors putting their money in commodity markets in the last decade. This is called financialization of commodity markets (see further in (Stoll and Whaley, 2010; Tang and Xiong, 2012)).

However, studies about commodities portfolio diversification benefits are limited. Existing studies about risks in commodity markets are limited to modeling volatility (Jacks et al., 2011; Vivian and Wohar, 2012; Creti et al., 2013). Another works investigating Value-at-Risk (VaR) in commodity markets are merely from a single asset perspective instead of a portfolio perspective.

For example, Cabedo and Moya (2003) quantify market risk using various VaR methods in the oil market. Another paper by Giot and Laurent (2003) evaluates the performance of several VaR models relevant in metals, energy and agriculture markets. Hung et al. (2008) use extended GARCH models to analyze the performance of one-day-ahead VaR estimates in five energy markets. None of them analyze portfolio diversification benefits and consequences of a portfolio consisting of several commodities. 
Indeed, an analysis of commodities as a portfolio (rather than a single asset) should generate more interest from investors since the portfolio enhances single asset due to diversification benefit (Edwards and Liew, 1999; You and Daigler, 2013). If we refer to a classical paper from Markowitz (1952) we will note that portfolio risk (i.e. variance) is named as an undesirable thing.

Therefore, a rational investor will prefer a portfolio combination so that the portfolio risk is reduced. When explaining about portfolio diversification benefits, we often provide a standard example: combining stocks with low correlations to construct a portfolio. Mathematically, we know that the portfolio risk (i.e. standard deviation) will be reduced.

In commodity markets we will also expect the reduced commodity portfolio risk. However, there is another question about the commodity portfolio risk measures. As the commodity portfolio standard deviation decreases, the commodity portfolio risk measures are also expected to decrease. However, how about the portfolio VaR and expected shortfall (ES)? Are there something unexpected consequences of the commodities portfolio? This is a research question that we would like to unmask in this paper. Therefore, this paper mainly explores the benefits and consequences of having commodities as a portfolio instead of a single asset.

This paper contributes to the literature in twofold. First, this paper extends further previous research on commodity volatility modeling by considering commodity portfolio volatility rather than a single commodity volatility. Second, it offers new perspective of investigating portfolio VaR and ES in commodity markets. This complements existing literature examining portfolio VaR in foreign exchange market (Chen et al., 2007) and stock and index markets (Lin and Ko, 2009; Goh et al., 2012; Palomba and Riccetti, 2012; Chen and Tu, 2013).

While there are recent works by Ghorbel and Trabelsi (2014) and Siburg et al. (2015) investigating portfolio VaR from energy markets, this paper differs from their works by developing various portfolios consisting of selected commodities and focusing on the diversification benefits and consequences of commodity portfolios.

The remainder of the paper is organized as follow. Section 2 provides a brief discussion about commodity markets and portfolio VaR and ES. Section 3 explains the method. Section 4 describes the data and discusses the empirical results. Section 5 concludes and provides suggestions for future research.

\section{Theoretical Background}

\subsection{Commodity Markets}

Routledge et al. (2000) provide a brief summary about the properties commodity markets that are different from standard financial assets (like bonds and stocks).

They document that: i) commodity futures prices tend to decrease with time-to-delivery, ii) commodities prices are mean reverting and strongly heteroskedastic, iii) the term structure of commodity forward price volatility tends to decrease with contract horizon, iv) strong seasonality in price levels and volatilities. Furthermore, Casassus and Dufresne (2005) argue that time varying risk in commodity markets is substantial. Therefore, we should incorporate this time varying risk when working on commodity markets.

In the first paragraph of the introduction section, we discuss about the financialization of commodity markets. In this part, we limit the financialized commodities in our terminology. First, we examine and compile literatures (Nakaso, 2011; Plantier, 2012; Baker, 2015) discussing financialized commodities. Then, we document that oil, natural gas, gold, silver, copper, corn, wheat and soybean are the most discussed commodities. Therefore, those commodities are the financialized commodities we refer to.

\subsection{Portfolio VaR and ES}

Basically, the portfolio VaR and ES are similar to a single asset VaR and ES. The difference is only calculating the portfolio standard deviation. In a single asset, we just calculate the standard deviation of the asset returns and then calculate the VaR and ES In a portfolio, it needs a bit more procedure since we have to calculate the standard deviation of the portfolio returns (this becomes complex when the portfolio consists of more than two assets). After obtaining the standard deviation of the portfolio returns, we can calculate the portfolio VaR and ES.

Portfolio VaR is the left tail of a portfolio return explaining the minimum losses of a portfolio during a trading period at a given confidence interval. Suppose a portfolio VaR is negative 10 percent for a weekly trading period at 95 percent confidence interval.

This means that the portfolio is expected to suffer loss at least 10 percent for 5 weeks for every 100 weeks trading period. Thus, we expect that there would be five losses more than 10 percent during the two years (104 weeks) weekly periods.

However, the VaR measure (both in single asset and portfolio) has a problem as a risk measure because VaR violates the subadditivity principle (Hull, 2007; Danielsson, 2011). An alternative risk measure that is subadditive is ES (see the proof in Artzner et al. (1999)). ES is an expected tail loss when a VaR limit is violated.

\section{Methodology}

\subsection{Portfolio Standard Deviation, VaR and ES}

We can calculate the variance of an equally weighted portfolio, $\sigma_{p}^{2}$, consisting of n-assets using the formula below.

$$
\sigma_{p}^{2}=w^{\prime} x \operatorname{Cov} x w=\left[\begin{array}{lll}
w_{1} & \cdots & w_{n}
\end{array}\right]\left[\begin{array}{ccc}
\operatorname{Cov}_{1,1} & \cdots & \operatorname{Cov}_{1, n} \\
\vdots & \ddots & \vdots \\
\operatorname{Cov}_{n, 1} & \cdots & \operatorname{Cov}_{n, n}
\end{array}\right]\left[\begin{array}{c}
w_{1} \\
\cdots \\
w_{n}
\end{array}\right]
$$

This paper use Equation 1 to calculate weighted portfolio variance, $\sigma_{p}^{2}$. Where $\mathrm{w}$ is a row matrix containing equal weight of $n$-assets and $\operatorname{Cov}_{n, n}$ is a covariance matrix of return series of n-assets. The portfolio standard deviation is the square root of the portfolio variance we obtain from Equation 1. 
An equally weighted portfolio is the equal weight of n-assets. Thus, if a portfolio consists of two assets, the equal weight would be 0.5 for asset 1 and 0.5 for asset 2. A portfolio consists of four assets would have 0.25 for asset $1,0.25$ for asset $2,0.25$ for asset 3 and 0.25 for asset 4 .

In this paper, an asset refers to a financialized commodity. We calculate the possible combinations of commodities portfolio in order to find the combination with the minimum commodities portfolio standard deviation. For instance, 2 commodities portfolio means that there are trials of combination between commodity 1 and commodity 2 up to 28 attempts. 3 commodities portfolio means that there are trials of combination among commodity 1, commodity 2, and commodity 3 up to 56 attempts. And so forth until 8 commodities portfolio. Table 1 demonstrates the possible trials of 2,3 and 4 commodities portfolios from 8 commodities.

Number 1, 2, 3,.., and 8 refers to each commodity: oil, natural gas, gold, silver, copper, corn, wheat, and soybean respectively. After obtaining portfolio's standard deviation, a portfolio VaR can be calculated as follow (Hull, 2007; Danielsson, 2011):

$$
\operatorname{VaR}_{p}=\sigma_{p} N^{-1}(X)
$$

In the Equation $2, \sigma_{\mathrm{p}}$ denotes the portfolio's standard deviation, $\mathrm{N}^{-1}(\mathrm{X})$ is the inverse cumulative normal distribution at X confidence level. A portfolio ES can be calculated as follow (Danielsson, 2011):

$$
E S_{p}=\sigma_{p}-\frac{\phi(\Phi(1-X))}{(1-X)}
$$

In the Equation $3, \sigma_{\mathrm{p}}$ denotes the portfolio's standard deviation, $\phi$ and $\Phi$ are the normal density and distribution, respectively, at $\mathrm{X}$ confidence level.

\subsection{Backtesting}

Backtesting is the procedure to compare the ex-ante (estimated) VaR with the ex-post (realized) return. The commodity portfolio $\mathrm{VaR}$ is estimated from the data during in-sample-period. We use 10 years rolling (moving) window to update the portfolio covariance matrix.

Then, we perform the backtesting during out-of-sample period to measure the VaR accuracy of the commodity portfolio. In this procedure, we can observe how many $\mathrm{VaR}$ violations occur in each portfolio combination $\mathrm{VaR}$ during the out-of-sample period.

\section{Empirical Analysis}

\subsection{Data}

Our sample includes eight financialized commodities: crude oil, natural gas, gold, silver, copper, corn, wheat and soybean. The choice of the commodities is motivated by our focus on financialized commodities that are most mentioned (Nakaso, 2011; Plantier, 2012; Baker, 2015). Table 2 elaborates further those commodities. 
Table-1. The possible trials of 2,3 and 4 commodities portfolios from 8 commodities.

\begin{tabular}{|c|c|c|c|c|c|c|c|c|c|c|c|}
\hline \multirow[t]{2}{*}{ Trial } & \multicolumn{2}{|c|}{2 commodities portfolio } & \multirow[t]{2}{*}{ Trial } & \multicolumn{3}{|c|}{3 commodities portfolio } & \multirow[t]{2}{*}{ Trial } & \multicolumn{4}{|c|}{4 commodities portfolio } \\
\hline & $\begin{array}{c}\text { Commodity } \\
1\end{array}$ & $\begin{array}{c}\text { Commodity } \\
2\end{array}$ & & $\begin{array}{c}\text { Commodity } \\
1\end{array}$ & $\begin{array}{c}\text { Commodity } \\
2\end{array}$ & $\begin{array}{c}\text { Commodity } \\
3\end{array}$ & & $\begin{array}{c}\text { Commodity } \\
1\end{array}$ & $\begin{array}{c}\text { Commodity } \\
2\end{array}$ & $\begin{array}{c}\text { Commodity } \\
3\end{array}$ & $\begin{array}{c}\text { Commodity } \\
4\end{array}$ \\
\hline 1 & 1 & 2 & 1 & 1 & 2 & 3 & 1 & 1 & 2 & 3 & 4 \\
\hline 2 & 1 & 3 & 2 & 1 & 2 & 4 & 2 & 1 & 2 & 3 & 5 \\
\hline 3 & 1 & 4 & 3 & 1 & 2 & 5 & 3 & 1 & 2 & 3 & 6 \\
\hline 4 & 1 & 5 & 4 & 1 & 2 & 6 & 4 & 1 & 2 & 3 & 7 \\
\hline$\ldots$ & & & & $\ldots$ & & & & & & & \\
\hline 26 & 6 & 7 & 54 & 5 & 6 & 8 & 68 & 4 & 5 & 7 & 8 \\
\hline 27 & 6 & 8 & 55 & 5 & 7 & 8 & 69 & 4 & 6 & 7 & 8 \\
\hline 28 & 7 & 8 & 56 & 6 & 7 & 8 & 70 & 5 & 6 & 7 & 8 \\
\hline
\end{tabular}


Table-2. Eight financialized commodities in our sample.

\begin{tabular}{c|c}
\hline Commodity & Remarks \\
\hline Oil & Crude oil-WTI \\
\hline Gas & Natural gas-Henry Hub \\
\hline Gold & Gold Bullion \\
\hline Silver & Silver, Handy Harman \\
\hline Copper & LME-Copper \\
\hline Corn & Corn No.2 \\
\hline Wheat & Wheat No.2 \\
\hline Soybean & Soybean meal \\
\hline
\end{tabular}

We use the in-sample period from January 1, 2000 to December 31, 2009 and the out-of-sample period from January 1, 2010 to December 31, 2015 (10 years of in-sample period and 6 years out of sample period). Our focus is financialized commodity markets. Therefore, we start the in-sample period at the time when the commodities entered financialization era and been identified to possess special properties. According to Rossi (2012) and Tang and Xiong (2012) the time is 2000. We end the in-sample period at 31-Dec-2009 to maintain consistency of 10 years period in many empirical finance works (see Ledoit and Wolf (2008)). We perform the stability tests in our yearly sub-sample analysis during the 6 years out-of-sample period. Furthermore, we use different data frequencies: i) daily, ii) weekly and iii) monthly in our sample since we want to obtain a robust finding. A robust finding is necessary because of data availability problem in the commodity markets (Narayan et al., 2013).

Table-3. Descriptive statistics of daily price change for eight financialized commodities.

\begin{tabular}{|c|c|c|c|c|c|c|c|c|}
\hline Commodity & Oil & Gas & Gold & Silver & Copper & Corn & Wheat & Soybean \\
\hline \multicolumn{9}{|c|}{ Panel A: All sample period (from 1-January-2000 to 31-December-2015) } \\
\hline Mean & $0.01 \%$ & $0.00 \%$ & $0.03 \%$ & $0.02 \%$ & $0.02 \%$ & $0.01 \%$ & $0.01 \%$ & $0.01 \%$ \\
\hline Standard deviation & $2.41 \%$ & $4.25 \%$ & $1.13 \%$ & $1.93 \%$ & $1.72 \%$ & $1.91 \%$ & $2.50 \%$ & $2.77 \%$ \\
\hline Minimum & $-17.09 \%$ & $-56.95 \%$ & $-10.16 \%$ & $-12.98 \%$ & $-10.36 \%$ & $-12.11 \%$ & $-22.59 \%$ & $-80.55 \%$ \\
\hline Maximum & $16.41 \%$ & $62.27 \%$ & $6.87 \%$ & $13.66 \%$ & $11.73 \%$ & $10.89 \%$ & $13.87 \%$ & $78.35 \%$ \\
\hline Range & $33.51 \%$ & $119.23 \%$ & $17.03 \%$ & $26.65 \%$ & $22.08 \%$ & $23.00 \%$ & $36.45 \%$ & $158.90 \%$ \\
\hline Number of observation & 4,174 & 4,174 & 4,174 & 4,174 & 4,174 & 4,174 & 4,174 & 4,174 \\
\hline \multicolumn{9}{|c|}{ Panel B: In-sample period (from 1-January-2000 to 31-December-2009) } \\
\hline Mean & $0.04 \%$ & $0.04 \%$ & $0.05 \%$ & $0.04 \%$ & $0.05 \%$ & $0.03 \%$ & $0.02 \%$ & $0.02 \%$ \\
\hline Standard deviation & $2.65 \%$ & $4.64 \%$ & $1.16 \%$ & $1.89 \%$ & $1.86 \%$ & $1.97 \%$ & $2.61 \%$ & $1.77 \%$ \\
\hline Minimum & $-17.09 \%$ & $-56.95 \%$ & $-7.14 \%$ & $-12.80 \%$ & $-10.36 \%$ & $-12.11 \%$ & $-22.59 \%$ & $-14.19 \%$ \\
\hline Maximum & $16.41 \%$ & $62.27 \%$ & $6.87 \%$ & $13.66 \%$ & $11.73 \%$ & $10.89 \%$ & $11.15 \%$ & $13.13 \%$ \\
\hline Range & $33.51 \%$ & $119.23 \%$ & $14.01 \%$ & $26.46 \%$ & $22.08 \%$ & $23.00 \%$ & $33.74 \%$ & $27.32 \%$ \\
\hline Number of observation & 2,609 & 2,609 & 2,609 & 2,609 & 2,609 & 2,609 & 2,609 & 2,609 \\
\hline \multicolumn{9}{|c|}{ Panel C: Out-of-sample period (from 1-January-2010 to 31-December-2015) } \\
\hline Mean & $-0.05 \%$ & $-0.06 \%$ & $0.00 \%$ & $-0.01 \%$ & $-0.03 \%$ & $0.00 \%$ & $0.00 \%$ & $0.00 \%$ \\
\hline Standard deviation & $1.95 \%$ & $3.49 \%$ & $1.08 \%$ & $1.98 \%$ & $1.45 \%$ & $1.80 \%$ & $2.32 \%$ & $3.92 \%$ \\
\hline Minimum & $-11.13 \%$ & $-27.02 \%$ & $-10.16 \%$ & $-12.98 \%$ & $-7.82 \%$ & $-9.32 \%$ & $-15.22 \%$ & $-80.55 \%$ \\
\hline Maximum & $9.90 \%$ & $37.81 \%$ & $5.43 \%$ & $7.73 \%$ & $6.68 \%$ & $9.31 \%$ & $13.87 \%$ & $78.35 \%$ \\
\hline Range & $21.02 \%$ & $64.83 \%$ & $15.59 \%$ & $20.72 \%$ & $14.50 \%$ & $18.63 \%$ & $29.08 \%$ & $158.90 \%$ \\
\hline Number of observation & 1,565 & 1,565 & 1,565 & 1,565 & 1,565 & 1,565 & 1,565 & 1,565 \\
\hline
\end{tabular}

Table 3 reports the descriptive statistics of daily return for eight financialized commodities. The descriptive statistics include the mean, standard deviation, minimum, maximum, range and the number of observation of each commodity. Panel A reports the descriptive statistics from January 1, 2000 to December 31, 2015 (all sample periods), Panel B reports the descriptive statistics from January 1, 2000 to December 31, 2009 (in-sample period) and Panel C reports the descriptive statistics from January 1, 2010 to December 31, 2015 (out-of- sample period).

According to Table 3, the daily returns range from 0.00 percent for gas to 0.03 percent for gold during all sample period, range from 0.02 percent for wheat and soybean to 0.05 percent for gold and copper during in-sample period and range from negative 0.06 percent for gas to 0.00 percent for gold and grains (corn, wheat and soybean) during out-of-sample period. We can see that gas tends to have the least average daily return while gold tends to have the highest average daily return. The volatilities of daily returns range from 1.13 percent for gold to 4.25 percent for gas during all sample period, range from 1.16 percent for gold to 4.64 percent for gas during in-sample period and range from 1.08 percent for gold to 3.92 percent for soybean during out-of-sample period. We can see that gold is the least volatile commodity while gas is the most volatile commodity. However, if we see the range, soybean has the highest range (159 percent) while gold has the lowest range (17 percent). Therefore, gold is consistently reported as the least volatile commodity while gas and soybean is reported as the most volatile commodity based on standard deviation and range values.

Table 4 lists the selected commodities to form our portfolio. The selection is based on the trials procedure as reported in the Table 1. Our portfolios consist of 2 commodities (P2), 3 commodities (P3), 4 commodities (P4), 5 commodities (P5), 6 commodities (P6), 7 commodities (P7) and 8 commodities (P8) for daily (Panel A), weekly (Panel B) and monthly (Panel C) series. According to the portfolio theory, the portfolio will gain diversification benefit at the most when the correlation among the assets is the lowest. Therefore, we choose the commodities in our portfolios based on the lowest portfolio standard deviation. 
Table-4. Detailed combination of commodities in our portfolio consisting of 2, 3, 4, 5, 6, 7 and 8 commodities for daily, weekly and monthly series.

\begin{tabular}{|c|c|c|c|c|c|c|c|c|}
\hline \multicolumn{9}{|c|}{ Equally weighted commodities } \\
\hline \multicolumn{9}{|c|}{ Panel A: Daily portfolio } \\
\hline $\mathrm{P2}$ & Gold & Soybean & & & & & & \\
\hline P3 & Gold & Corn & Soybean & & & & & \\
\hline $\mathbf{P 4}$ & Gold & Copper & Corn & Soybean & & & & \\
\hline P5 & Gold & Silver & Copper & Corn & Soybean & & & \\
\hline P6 & Oil & Gold & Silver & Copper & Corn & Soybean & & \\
\hline P7 & Oil & Gold & Silver & Copper & Corn & Wheat & Soybean & \\
\hline P8 & Oil & Gas & Gold & Silver & Copper & Corn & Wheat & Soybean \\
\hline \multicolumn{9}{|c|}{ Panel B: Weekly portfolio } \\
\hline $\mathbf{P 2}$ & Gold & Soybean & & & & & & \\
\hline P3 & Gold & Copper & Soybean & & & & & \\
\hline $\mathbf{P 4}$ & Gold & Copper & Corn & Soybean & & & & \\
\hline P5 & Gold & Silver & Copper & Corn & Soybean & & & \\
\hline P6 & Gold & Silver & Copper & Corn & Wheat & Soybean & & \\
\hline P7 & Oil & Gold & Silver & Copper & Corn & Wheat & Soybean & \\
\hline P8 & Oil & Gas & Gold & Silver & Copper & Corn & Wheat & Soybean \\
\hline \multicolumn{9}{|c|}{ Panel C: Monthly portfolio } \\
\hline $\mathbf{P 2}$ & Gold & Soybean & & & & & & \\
\hline P3 & Gold & Copper & Soybean & & & & & \\
\hline $\mathbf{P 4}$ & Gold & Copper & Corn & Soybean & & & & \\
\hline P5 & Gold & Silver & Copper & Corn & Soybean & & & \\
\hline P6 & Oil & Gold & Silver & Copper & Corn & Soybean & & \\
\hline P7 & Oil & Gold & Silver & Copper & Corn & Wheat & Soybean & \\
\hline P8 & Oil & Gas & Gold & Silver & Copper & Corn & Wheat & Soybean \\
\hline
\end{tabular}

\begin{tabular}{c|c|c|c}
\hline Table-5. The average of standard deviations of commodities and portfolios returns for daily, weekly and monthly series. \\
\hline Commodity / & \multicolumn{3}{|c}{ Average standard deviation } \\
\hline Portfolio & Daily & Weekly & Monthly \\
\hline Oil & $2.43 \%$ & $5.66 \%$ & $9.91 \%$ \\
\hline Gas & $4.17 \%$ & $8.86 \%$ & $18.88 \%$ \\
\hline Gold & $1.22 \%$ & $2.74 \%$ & $5.25 \%$ \\
\hline Silver & $2.12 \%$ & $4.78 \%$ & $10.11 \%$ \\
\hline Copper & $1.95 \%$ & $4.02 \%$ & $9.01 \%$ \\
\hline Corn & $2.08 \%$ & $4.62 \%$ & $10.34 \%$ \\
\hline Wheat & $2.76 \%$ & $5.54 \%$ & $6.71 \%$ \\
\hline Soybean & $2.01 \%$ & $3.83 \%$ & $10.31 \%$ \\
\hline Average commodity & $2.34 \%$ & $5.01 \%$ & $4.08 \%$ \\
\hline P2 & $1.19 \%$ & $2.34 \%$ & $4.53 \%$ \\
\hline P3 & $1.12 \%$ & $2.33 \%$ & $5.08 \%$ \\
\hline P4 & $1.09 \%$ & $2.43 \%$ & $5.47 \%$ \\
\hline P5 & $1.14 \%$ & $2.92 \%$ & $5.54 \%$ \\
\hline P6 & $1.17 \%$ & $2.64 \%$ & $5.81 \%$ \\
\hline P7 & $1.20 \%$ & $2.67 \%$ & $6.07 \%$ \\
\hline P8 & $1.23 \%$ & $2.73 \%$ & $5.23 \%$ \\
\hline Average portfolio & $1.16 \%$ & $2.58 \%$ & \\
\hline
\end{tabular}

\subsection{Commodities Volatility and Portfolio Volatility}

Table 5 reports the average of standard deviations of commodities and portfolios returns for daily, weekly and monthly series. As expected, we see the diversification benefits here. The average standard deviation of return series for each commodity as a single asset ranges from 1.22 percent to 4.17 percent (daily), from 2.74 percent to 8.86 percent (weekly) and from 5.25 percent to 18.88 percent (monthly). The average standard deviation of return series for each portfolio combination range from 1.09 percent to 1.23 percent (daily), from 2.33 percent to 2.92 percent (weekly) and from 4.08 percent to 6.07 percent (monthly). The average standard deviations of return series for all commodities are 2.34 percent (daily), 5.01 percent (weekly) and 10.31 percent (monthly) while the average standard deviations of return series for all portfolios are 1.16 percent (daily), 2.58 percent (weekly) and 5.23 percent (monthly). Overall, we can conclude that there is diversification benefit here, the reduced risk when the commodities are bundled as a portfolio rather than just a single asset. Another implied diversification benefit is the reduced capital requirement. The capital requirement is normally calculated using VaR approach (see Jorion (2007)). Therefore, the lower standard deviation is associated with lower capital required.

\subsection{Back-Testing Result}

Table 6 reports the results of back-testing VaR commodities and portfolios for eight financialized commodities and seven combination portfolios at different VaR levels (99 percent, 95 percent and 90 percent) and at different out-of-sample periods ( 1 year, 2 years, 3 years, 4 years, 5 years, and 6 years) for daily (Panel A), weekly (Panel B) and monthly (Panel C) return series. The reported numbers are the number of VaR violations. A VaR violation occurs when a return (usually negative) is smaller than left-tailed VaR limit in the designated confidence level. In the right column after soybean commodity and $\mathrm{P} 8$, we report the average number of VaR violations for eight commodities and seven portfolios, respectively.

In the Panel A (daily series), we can see that the average numbers of VaR violations for portfolios are lower than the average numbers of $\mathrm{VaR}$ violations for commodities. The results are consistent for all different out-ofsample periods. However, these consistent results are for the VaR 99 level only. For the VaR 95 and 90 levels, most 
of the average numbers of VaR violations for portfolios are higher than the average numbers of VaR violations for commodities. This indicates that even though commodities portfolio generates another benefit of having more accurate VaR, unfortunately, the benefit is applicable only in 99 percent VaR.

We obtain similar results in the Panel B (weekly series). The average numbers of VaR violations for portfolios are lower than the average numbers of VaR violations for commodities only for the VaR 99 level only for weekly series. For monthly series (Panel C), the reduced VaR violations for portfolio are only applicable at certain out-ofsample period for the VaR 95 level. For the rest, most of the average portfolios have higher numbers of VaR violations. This indicates that the portfolio diversification benefit of having more accurate VaR only comes at VaR 99 level for weekly series and somewhat at VaR 95 level for monthly series.

Table 7 reports the numbers of returns that are lower than ES of eight financialized commodities and seven combination portfolios at different VaR levels (99 percent, 95 percent and 90 percent) and at different out-ofsample periods ( 1 year, 2 years, 3 years, 4 years, 5 years, and 6 years) for daily (Panel A), weekly (Panel B) and monthly (Panel C) return series.

In the Panel A (daily series), we also see that the average numbers of returns that are lower than ES for the portfolios are less than the average numbers of returns that are lower than ES for the commodity. The results are consistent for all different out-of-sample periods. However, these consistent results are for the 99 percent confidence level only and even slightly worse than the results of backtesting VaR 99 Table 6 Panel A because there is a worse result for portfolio. For the 95 and 90 percent confidence levels, most of the average numbers of returns that are lower than ES for portfolios are bigger than the average numbers of returns that are lower than ES for commodities. Again, this indicates that both VaR and ES measures confirm that commodity portfolio possess unexpected consequence by having, on average, less accurate VaR and more left-tailed returns that below the ES.

We obtain similar results in the Panel B (weekly series). The average numbers of returns that are lower than ES for the portfolios are less than the average numbers of returns that are lower than ES for the commodity only 99 percent confidence level. For monthly series (Panel C), the reduced average numbers of returns that are lower than ES portfolio are only applicable at certain out-of-sample period for the 95 percent confidence level. For the rest, most of the average portfolios have higher average numbers of returns that are lower than ES. This indicates that the portfolio diversification benefit based on ES measure is only applicable at 99 percent confidence level for weekly series and somewhat at 95 percent confidence level for monthly series.

Overall, we can see that even tough commodities portfolios possess diversification benefit of having lower risk, the lower risk somewhat becomes contradictory since the VaR position will be less conservative. This enables possibilities of having left-tailed return violating VaR limit. Our finding is also confirmed by our ES analysis. Therefore, we can see both benefits and unintended consequences of commodities portfolio. The benefits are lowering risk and reducing the capital requirements (because of lower VaR), as reported in the Table 5. On the other hand, the portfolio also has less accurate VaR and more returns that are lower than ES, as reported in the Table 6 and Table 7, respectively.

\section{Conclusions}

This paper investigates the benefits and consequences of portfolio in financialized commodity markets. We use eight financialized commodities at different data frequencies (daily, weekly and monthly) to construct seven equally weighted portfolios. Our choice of commodities in forming the portfolios is based on the minimum value of portfolios standard deviation among possible portfolio combinations. We use moving average for obtaining portfolios covariance and then calculating the portfolios standard deviation. After that, we calculate portfolios VaR and ES. Finally, we perform back testing VaR and calculate the number of returns that are lower than ES at 99 percent, 95 percent and 90 percent VaR levels.

We demonstrate that the average standard deviation of the portfolios are smaller than the average standard deviation of the commodity. This mean that commodities bundled as a portfolio have lower risk than commodity as a single asset. This also implies that investors will require fewer capital when investing in commodity portfolio rather than investing in commodity as a single asset. Therefore, reducing risk and capital requirement are the diversification benefits of financialized commodities portfolio.

On the other hand, we find that on average commodities portfolios tend to have less accurate VaR and more returns that are lower than ES. Our results are consistent for daily, weekly and monthly series and at different outof-sample periods at the most confidence levels. The more accurate of the average commodity portfolios VaR over the average of single commodity VaR is reported only at 99 percent VaR level for daily and weekly series (across all out-of-sample periods). For monthly series, only few average numbers of commodity portfolio VaR are reported to be more accurate than single commodity VaR. We also obtain similar results when performing ES analysis. The commodity portfolios tend to have higher average number of returns that are lower than ES compared with single commodity. Overall, we find unintended consequences of diversification benefits in commodity portfolios. On one side, there are clearly diversification benefits of having lower risk and implying reduced capital requirement in commodity portfolio. On the other hand, there are unintended consequences by having less accurate VaR and higher number of returns that are lower than ES.

Our results are based on the standard variance-covariance portfolio volatility method, which could be one of our limitations. Investigating portfolio VaR and ES using more advanced volatility methods are encouraged to discover other possible diversification benefits and consequences of having commodities in a portfolio rather than in a single asset. 

out-of-sample periods ( 1 year, 2 years, 3 years, 4 years, 5 years, and 6 years) for daily, weekly and monthly return series.

\begin{tabular}{|c|c|c|c|c|c|c|c|c|c|c|c|c|c|c|c|c|c|c|}
\hline \multicolumn{19}{|c|}{ Panel A: Number of VaR violations - Daily series } \\
\hline $\begin{array}{l}\text { VaR } \\
\text { level }\end{array}$ & $\begin{array}{c}\text { Commodity / portfolio } \\
\text { Out-of-sample period }\end{array}$ & Oil & Gas & Gold & Silver & Copper & Corn & Wheat & Soybean & $\begin{array}{l}\text { AVG } \\
\text { COM }\end{array}$ & $\mathbf{P 2}$ & P3 & $\mathbf{P}_{4}$ & P5 & P6 & P7 & P8 & $\begin{array}{c}\mathrm{AVG} \\
\mathrm{P} \\
\end{array}$ \\
\hline \multirow{6}{*}{ VaR 99} & 1 Year & 0 & 2 & 1 & 6 & 5 & 4 & 5 & $\overline{2}$ & 3.13 & 3 & 4 & 3 & 3 & 0 & 2 & 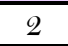 & 2.52 \\
\hline & 2 Years & 4 & 3 & 10 & 23 & 9 & 9 & 10 & 2 & 8.75 & 5 & 7 & 7 & 13 & 6 & 11 & 8 & 8.22 \\
\hline & 3 Years & 4 & 3 & 14 & 25 & 9 & 13 & 10 & 2 & 10.00 & 6 & 9 & 9 & 15 & 6 & 12 & 9 & 9.50 \\
\hline & 4. Years & 4 & 3 & 21 & 29 & 9 & 19 & 11 & 4 & 12.50 & 12 & 14 & 11 & 17 & 8 & 14 & 11 & 12.44 \\
\hline & 5 Years & 6 & 11 & 21 & 32 & 9 & 20 & 13 & 7 & 14.88 & 15 & 15 & 12 & 18 & 10 & 15 & 13 & 14.11 \\
\hline & 6 Years & 13 & 13 & 21 & 34 & 11 & 23 & 13 & 10 & 17.25 & 18 & 18 & 15 & 21 & 13 & 18 & 16 & 17.03 \\
\hline \multirow{6}{*}{ VaR 95} & 1 Year & 4 & 5 & 10 & 11 & 11 & 9 & 8 & 3 & 7.63 & 4 & 6 & 10 & 11 & 5 & 10 & 6 & 7.45 \\
\hline & 2 Years & 13 & 6 & 28 & 37 & 23 & 22 & 23 & 5 & 19.63 & 13 & 20 & 25 & 32 & 16 & 24 & 21 & 21.33 \\
\hline & 3 Years & 17 & 9 & 35 & 44 & 26 & 28 & 26 & 9 & 24.25 & 19 & 29 & 30 & 39 & 19 & 30 & 24 & 26.78 \\
\hline & 4. Years & 17 & 10 & 50 & 58 & 27 & 37 & 27 & 18 & 30.50 & 31 & 39 & 38 & 48 & 22 & 33 & 26 & 33.44 \\
\hline & 5 Years & 26 & 24 & 52 & 62 & 28 & 38 & 32 & 23 & 35.63 & 34 & 42 & 40 & 51 & 24 & 36 & 34 & 37.08 \\
\hline & 6 Years & 51 & 31 & 58 & 69 & 33 & 43 & 36 & 27 & 43.50 & 38 & 48 & 45 & 56 & 27 & 40 & 38 & 41.94 \\
\hline \multirow{6}{*}{ VaR 90} & 1 Year & 11 & 8 & 21 & 17 & 20 & 16 & 16 & 5 & 14.25 & 9 & 17 & 18 & 17 & 10 & 17 & 11 & 14.16 \\
\hline & 2 Years & 25 & 10 & 48 & 54 & 44 & 45 & 44 & 10 & 35.00 & 29 & 43 & 46 & 48 & 32 & 43 & 34 & 38.75 \\
\hline & 3 Years & 36 & 16 & 63 & 67 & 55 & 58 & 54 & 23 & 46.50 & 42 & 61 & 64 & 62 & 39 & 56 & 42 & 51.56 \\
\hline & 4 Years & 37 & 17 & 87 & 87 & 60 & 73 & 57 & 37 & 56.88 & 62 & 80 & 79 & 85 & 48 & 65 & 47 & 65.36 \\
\hline & 5 Years & 51 & 36 & 97 & 98 & 64 & 79 & 68 & 51 & 68.00 & 67 & 87 & 82 & 92 & 54 & 73 & 62 & 73.13 \\
\hline & 6 Years & 86 & 50 & 107 & 111 & 78 & 86 & 79 & 55 & 81.50 & 71 & 95 & 91 & 100 & 62 & 83 & 71 & 81.81 \\
\hline & & & & & nel B: N & nber of $V$ & violat & is - Wee & series & & & & & & & & & \\
\hline $\begin{array}{l}\text { VaR } \\
\text { level }\end{array}$ & $\begin{array}{c}\text { Commodity / portfolio } \\
\text { Out-of-sample period }\end{array}$ & Oil & Gas & Gold & Silver & Copper & Corn & Wheat & Soybean & $\begin{array}{l}\text { AVG } \\
\text { COM }\end{array}$ & P2 & P3 & P4 & P5 & P6 & P7 & P8 & $\begin{array}{c}\text { AVG } \\
P\end{array}$ \\
\hline & 1 Year & 0 & 0 & 0 & 0 & 3 & 1 & 1 & 1 & 0.75 & 0 & 0 & 0 & 0 & 0 & 0 & 0 & 0.09 \\
\hline & 2 Years & 1 & 0 & 1 & 2 & 5 & 2 & 1 & 1 & 1.63 & 1 & 1 & 2 & 1 & 1 & 2 & 2 & 1.45 \\
\hline $\mathrm{V} P \mathrm{~B}$ & 3 Years & 1 & 0 & 1 & 2 & 5 & 2 & 1 & 1 & 1.63 & 1 & 1 & 2 & 1 & 1 & 2 & 2 & 1.45 \\
\hline VaR 99 & 4 Years & 1 & 0 & 3 & 3 & 5 & 5 & 1 & 1 & 2.38 & 2 & 1 & 3 & 1 & 1 & 2 & 2 & 1.80 \\
\hline & 5 Years & 1 & 2 & 3 & 3 & 5 & 5 & 2 & 1 & 2.75 & 2 & 1 & 3 & 1 & 1 & 2 & 2 & 1.84 \\
\hline & 6 Years & 2 & 2 & 3 & 3 & 5 & 5 & 2 & 3 & 3.13 & 4 & 3 & 5 & 3 & 3 & 4 & 3 & 3.52 \\
\hline & 1 Year & 1 & 0 & 0 & 2 & 3 & 1 & 2 & 2 & 1.38 & 1 & 3 & 2 & 0 & 2 & 1 & 1 & 1.42 \\
\hline & 2 Years & 3 & 0 & 3 & 6 & 6 & 6 & 4 & 3 & 3.88 & 3 & 6 & 6 & 4 & 7 & 6 & 6 & 5.23 \\
\hline VO & 3 Years & 3 & 0 & 4 & 6 & 6 & 8 & 4 & 4 & 4.38 & 4 & 8 & 7 & 4 & 7 & 6 & 6 & 5.80 \\
\hline vak 95 & 4 Years & 3 & 0 & 8 & 8 & 6 & 12 & 5 & 5 & 5.88 & 6 & 10 & 10 & 7 & 9 & 7 & 6 & 7.61 \\
\hline & 5 Years & 6 & 3 & 9 & 9 & 6 & 13 & 9 & 7 & 7.75 & 7 & 10 & 10 & 7 & 10 & 7 & 7 & 8.22 \\
\hline & 6 Years & 9 & 4 & 9 & 9 & 7 & 14 & 10 & 10 & 9.00 & 10 & 13 & 13 & 9 & 14 & 11 & 10 & 11.13 \\
\hline & 1 Year & 4 & 0 & 1 & 3 & 6 & 6 & 2 & 3 & 3.13 & 3 & 4 & 5 & 2 & 4 & 3 & 2 & 3.27 \\
\hline $\mathrm{V}=\mathrm{R}$ op & 2 Years & 7 & 0 & 8 & 11 & 10 & 13 & 5 & 4 & 7.25 & 6 & 8 & 9 & 6 & 11 & 11 & 8 & 8.28 \\
\hline VaR 90 & 3 Years & 8 & 2 & 10 & 12 & 10 & 15 & 5 & 6 & 8.50 & 8 & 10 & 11 & 8 & 13 & 12 & 9 & 9.94 \\
\hline & 4 Years & 8 & 2 & 14 & 15 & 11 & 20 & 7 & 10 & 10.88 & 15 & 12 & 16 & 12 & 18 & 16 & 12 & 13.98 \\
\hline
\end{tabular}


Asian Business Research Journal, 2019, 4: 17-28

\begin{tabular}{|c|c|c|c|c|c|c|c|c|c|c|c|c|c|c|c|c|c|c|}
\hline & 5 Years & 12 & 7 & 17 & 17 & 11 & 22 & 12 & 14 & 14.00 & 17 & 12 & 17 & 12 & 21 & 19 & 15 & 15.88 \\
\hline & 6 Years & 19 & 13 & 19 & 17 & 15 & 25 & 16 & 17 & 17.63 & 20 & 15 & 22 & 15 & 26 & 24 & 20 & 19.95 \\
\hline \multicolumn{19}{|c|}{ Panel C: Number of VaR violations - Monthly series } \\
\hline \multirow{2}{*}{$\begin{array}{c}\text { VaR } \\
\text { level }\end{array}$} & Commodity / portfolio & \multirow{2}{*}{ Oil } & \multirow{2}{*}{ Gas } & \multirow{2}{*}{ Gold } & \multirow{2}{*}{ Silver } & \multirow{2}{*}{ Copper } & \multirow{2}{*}{ Corn } & \multirow{2}{*}{ Wheat } & \multirow{2}{*}{ Soybean } & AVG & \multirow{2}{*}{ P2 } & \multirow{2}{*}{ P3 } & \multirow{2}{*}{ P4 } & \multirow{2}{*}{ P5 } & \multirow{2}{*}{ P6 } & \multirow{2}{*}{ P7 } & \multirow{2}{*}{ P8 } & AVG \\
\hline & Out-of-sample period & & & & & & & & & COM & & & & & & & & $\mathbf{P}$ \\
\hline \multirow{6}{*}{ VaR 99} & 1 Year & 0 & 0 & 0 & 0 & 0 & 0 & 0 & 0 & 0.00 & 0 & 0 & 0 & 0 & 0 & 0 & 0 & 0.00 \\
\hline & 2 Years & 0 & 0 & 0 & 1 & 1 & 1 & 0 & 0 & 0.38 & 0 & 1 & 1 & 1 & 1 & 1 & 1 & 0.80 \\
\hline & 3 Years & 1 & 0 & 0 & 1 & 1 & 1 & 0 & 0 & 0.50 & 0 & 1 & 1 & 1 & 1 & 1 & 1 & 0.81 \\
\hline & 4 Years & 1 & 0 & 0 & 1 & 1 & 2 & 0 & 0 & 0.63 & 0 & 1 & 2 & 1 & 1 & 1 & 1 & 0.95 \\
\hline & 5 Years & 1 & 1 & 0 & 1 & 1 & 3 & 1 & 0 & 1.00 & 0 & 1 & 2 & 1 & 1 & 2 & 1 & 1.13 \\
\hline & 6 Years & 3 & 1 & 0 & 1 & 1 & 3 & 1 & 0 & 1.25 & 0 & 1 & 2 & 1 & 1 & 2 & 1 & 1.16 \\
\hline \multirow{6}{*}{ VaR 95} & 1 Year & 1 & 0 & 0 & 0 & 0 & 0 & 0 & 0 & 0.13 & 0 & 0 & 0 & 0 & 0 & 0 & 0 & 0.02 \\
\hline & 2 Years & 1 & 0 & 1 & 2 & 1 & 2 & 2 & 0 & 1.13 & 1 & 1 & 1 & 1 & 1 & 1 & 1 & 1.02 \\
\hline & 3 Years & 2 & 0 & 2 & 2 & 1 & 2 & 2 & 1 & 1.50 & 1 & 1 & 1 & 1 & 2 & 2 & 1 & 1.31 \\
\hline & 4 Years & 2 & 0 & 4 & 3 & 1 & 3 & 2 & 1 & 2.00 & 3 & 1 & 2 & 2 & 3 & 2 & 1 & 2.00 \\
\hline & 5 Years & 2 & 1 & 4 & 3 & 1 & 4 & 3 & 1 & $\begin{array}{l}2.38 \\
\end{array}$ & 4 & 1 & 3 & 3 & 4 & 3 & 22 & 2.80 \\
\hline & 6 Years & 4 & 1 & 4 & 3 & 1 & 4 & 3 & 1 & $\begin{array}{l}2.63 \\
\end{array}$ & 4 & 2 & 4 & 3 & 5 & 4 & 3 & 3.45 \\
\hline \multirow{6}{*}{ VaR 90} & 1 Year & 1 & 0 & 1 & 1 & 0 & 1 & 0 & 0 & 0.50 & 0 & 0 & 1 & 0 & 0 & $\mathrm{O}$ & 0 & 0.19 \\
\hline & 2 Years & 2 & 0 & 3 & 3 & 1 & 3 & 2 & 0 & 1.75 & 1 & 1 & 2 & 2 & 1 & 2 & 2 & 1.59 \\
\hline & 3 Years & 3 & 2 & 4 & 4 & 2 & 3 & 2 & 1 & 2.63 & 1 & 1 & 3 & 3 & 2 & 3 & 3 & 2.33 \\
\hline & 4 Years & 3 & 2 & 7 & 6 & 2 & 4 & 2 & 2 & 3.50 & 3 & 2 & 4 & 5 & 3 & 4 & 4 & 3.56 \\
\hline & 5 Years & 5 & 3 & 7 & 6 & 2 & 6 & 4 & 4 & $\begin{array}{l}4.63 \\
\end{array}$ & 4 & 3 & 5 & 6 & 4 & 5 & 6 & 4.70 \\
\hline & 6 Years & 8 & 4 & 7 & 6 & 3 & 6 & 6 & 4 & 5.50 & 5 & 5 & 6 & 7 & 5 & 6 & 7 & 5.81 \\
\hline
\end{tabular}


Table-7. The reported numbers of returns that are lower than ES of eight financialized commodities and seven combination portfolios at different VaR levels (99 percent, 95 percent and 90 percent) and at different out-ofsample periods ( 1 year, 2 years, 3 years, 4 years, 5 years, and 6 years) for daily, weekly and monthly return series

\begin{tabular}{|c|c|c|c|c|c|c|c|c|c|c|c|c|c|c|c|c|c|c|}
\hline \multirow[b]{2}{*}{$\begin{array}{c}\text { Confidence } \\
\text { level }\end{array}$} & & \multicolumn{17}{|c|}{ Panel A: Number of returns that are lower than ES - Daily series } \\
\hline & $\begin{array}{c}\text { Commodity / portfolio } \\
\text { Out-of-sample period }\end{array}$ & Oil & Gas & Gold & Silver & Copper & Corn & Wheat & Soybean & $\begin{array}{l}\text { AVG } \\
\text { COM }\end{array}$ & $\mathrm{P} 2$ & P3 & P4 & P5 & P6 & P7 & P8 & $\frac{\text { AVG }}{\text { P }}$ \\
\hline \multirow{6}{*}{99 percent } & 1 Year & $\overline{0}$ & 1 & 1 & 2 & 4 & 3 & 3 & 2 & 2.00 & 1 & 1 & 1 & 1 & 0 & 2 & 0 & 1.00 \\
\hline & 2 Years & 2 & 2 & 6 & 15 & 7 & 6 & 7 & 2 & 5.88 & 3 & 2 & 4 & 5 & 4 & 10 & 5 & 4.86 \\
\hline & 3 Years & 2 & 2 & 8 & 15 & 7 & 8 & 7 & 2 & 6.38 & 3 & 3 & 5 & 5 & 4 & 10 & 5 & 5.17 \\
\hline & 4. Years & 2 & 2 & 11 & 17 & 7 & 11 & 8 & 3 & 7.63 & 6 & 7 & 6 & 7 & 6 & 12 & 6 & 7.20 \\
\hline & 5 Years & 3 & 9 & 11 & 19 & 7 & 11 & 9 & 4 & 9.13 & 8 & 8 & 7 & 8 & 7 & 13 & 7 & 8.39 \\
\hline & 6 Years & 7 & 11 & 11 & 21 & 8 & 13 & 9 & 7 & 10.88 & 11 & 11 & 10 & 11 & 10 & 16 & 10 & 11.23 \\
\hline \multirow{6}{*}{95 percent } & 1 Year & 0 & 2 & 2 & 7 & 6 & 5 & 5 & 2 & 3.63 & 3 & 5 & 5 & 5 & 3 & 5 & 2 & 3.95 \\
\hline & 2 Years & 7 & 3 & 15 & 26 & 12 & 13 & 10 & 2 & 11.00 & 8 & 11 & 13 & 18 & 10 & 16 & 11 & 12.25 \\
\hline & 3 Years & 7 & 4 & 20 & 30 & 12 & 18 & 10 & 3 & 13.00 & 11 & 15 & 15 & 22 & 11 & 18 & 12 & 14.63 \\
\hline & 4. Years & 7 & 4 & 29 & 38 & 12 & 24 & 11 & 7 & 16.50 & 18 & 22 & 18 & 24 & 13 & 20 & 14 & 18.19 \\
\hline & 5 Years & 11 & 14 & 30 & 42 & 12 & 25 & 14 & 10 & 19.75 & 21 & 24 & 19 & 25 & 15 & 21 & 17 & 20.22 \\
\hline & 6 Years & 27 & 18 & 31 & 46 & 14 & 28 & 15 & 14 & 24.13 & 25 & 28 & 22 & 28 & 18 & 24 & 21 & 23.77 \\
\hline \multirow{6}{*}{90 percent } & 1 Year & 2 & 3 & 9 & 11 & 9 & 9 & 6 & 3 & 6.50 & 4 & 5 & 9 & 8 & 4 & 8 & 5 & 6.19 \\
\hline & 2 Years & 11 & 4 & 25 & 34 & 18 & 21 & 14 & 3 & 16.25 & 11 & 18 & 19 & 27 & 13 & 21 & 19 & 18.03 \\
\hline & 3 Years & 12 & 6 & 31 & 41 & 19 & 27 & 17 & 6 & 19.88 & 15 & 26 & 23 & 33 & 15 & 26 & 22 & 22.48 \\
\hline & 4 Years & 12 & 7 & 44 & 52 & 20 & 34 & 18 & 14 & 25.13 & 26 & 33 & 29 & 39 & 17 & 28 & 24 & 27.64 \\
\hline & 5 Years & 21 & 20 & 45 & 56 & 21 & 35 & 22 & 18 & 29.75 & 29 & 35 & 31 & 411 & 19 & 31 & 32 & 30.97 \\
\hline & 6 Years & 43 & 27 & 49 & 62 & 25 & 40 & 24 & 22 & 36.50 & 33 & 41 & 34 & 45 & 22 & 34 & 36 & 35.19 \\
\hline \multicolumn{19}{|c|}{ Panel B: Number of returns that are lower than ES - Weekly series } \\
\hline $\begin{array}{c}\text { Confidence } \\
\text { level }\end{array}$ & $\begin{array}{l}\text { Commodity / portfolio } \\
\text { Out-of-sample period }\end{array}$ & Oil & Gas & Gold & Silver & Copper & Corn & Wheat & Soybean & $\begin{array}{l}\text { AVG } \\
\text { COM }\end{array}$ & $\mathrm{P} 2$ & P3 & P4 & P5 & P6 & P7 & P8 & $\frac{\text { AVG }}{P}$ \\
\hline & 1 Year & 0 & 0 & 0 & 0 & 1 & 1 & 0 & 1 & 0.75 & 0 & 0 & 0 & 0 & 0 & 0 & 0 & 0.09 \\
\hline & 2 Years & 0 & 0 & 1 & 2 & 2 & 1 & $\mathrm{O}$ & 1 & 1.63 & 1 & 1 & 1 & 1 & 1 & 1 & 1 & 1.45 \\
\hline 09 nercent & 3 Years & 0 & 0 & 1 & 2 & 2 & 1 & 0 & 1 & 1.63 & 1 & 1 & 1 & 1 & 1 & 1 & 1 & 1.45 \\
\hline 99 percent & 4 Years & 0 & 0 & 2 & 3 & 2 & 4 & 0 & 1 & 2.38 & 1 & 1 & 1 & 1 & 1 & 1 & 1 & 1.80 \\
\hline & 5 Years & 0 & 2 & 2 & 3 & 2 & 4 & 0 & 1 & 2.75 & 1 & 1 & 1 & 1 & 1 & 1 & 1 & 1.84 \\
\hline & 6 Years & 0 & 2 & 2 & 3 & 2 & 4 & 0 & 3 & 3.13 & 3 & 3 & 3 & 3 & 3 & 3 & 2 & 3.52 \\
\hline & 1 Year & 0 & 0 & 0 & 0 & 3 & 1 & 1 & 2 & 1.38 & 0 & 1 & 0 & 0 & 0 & 0 & 0 & 1.42 \\
\hline & 2 Years & 1 & 0 & 2 & 2 & 5 & 3 & 1 & 2 & 3.88 & 2 & 3 & 2 & 2 & 3 & 2 & 2 & 5.23 \\
\hline 05 nercent & 3 Years & 1 & 0 & 2 & 2 & 5 & 3 & 1 & 2 & 4.38 & 2 & 3 & 2 & 2 & 3 & 2 & 2 & 5.80 \\
\hline 95 percent & 4. Years & 1 & 0 & 4 & 4 & 5 & 6 & 1 & 2 & 5.88 & 3 & 3 & 3 & 2 & 3 & 2 & 2 & 7.61 \\
\hline & 5 Years & 2 & 3 & 4 & 4 & 5 & 6 & 3 & 3 & 7.75 & 3 & 3 & 3 & 2 & 3 & 2 & 3 & 8.22 \\
\hline & 6 Years & 3 & 4 & 4 & 4 & 5 & 6 & 3 & 5 & 9.00 & 5 & 5 & 6 & 4 & 5 & 4 & 5 & 11.13 \\
\hline & 1 Year & 1 & 0 & 0 & 2 & 3 & 1 & 2 & 2 & 3.13 & 1 & 2 & 1 & 0 & 1 & 1 & 0 & 3.27 \\
\hline OO norcont & 2 Years & 3 & 0 & 3 & 6 & 5 & 5 & 4 & 3 & 7.25 & 3 & 4 & 4 & 4 & 5 & 4 & 3 & 8.28 \\
\hline 90 percent & 3 Years & 3 & 0 & 3 & 6 & 5 & 7 & 4 & 4 & 8.50 & 4 & 4 & 5 & 4 & 5 & 4 & 3 & 9.94 \\
\hline & 4 Years & 3 & 0 & 7 & 8 & 5 & 11 & 5 & 5 & 10.88 & 6 & 6 & 7 & 6 & 6 & 5 & 3 & 13.98 \\
\hline
\end{tabular}


Asian Business Research Journal, 2019, 4: 17-28

\begin{tabular}{|c|c|c|c|c|c|c|c|c|c|c|c|c|c|c|c|c|c|c|}
\hline & 5 Years & 5 & 3 & 8 & 8 & 5 & 11 & 9 & 6 & 14.00 & 6 & 6 & 7 & 6 & 6 & 5 & 4 & 15.88 \\
\hline & 6 Years & 7 & 4 & 8 & 8 & 5 & 12 & 9 & 9 & 17.63 & 8 & 9 & 10 & 8 & 9 & 8 & 6 & 19.95 \\
\hline \multicolumn{19}{|c|}{ Panel C: Number of returns that are lower than ES - Monthly series } \\
\hline $\begin{array}{c}\text { Confidence } \\
\text { level }\end{array}$ & Commodity / portfolio & Oil & Gas & Gold & Silver & Copper & Corn & Wheat & Soybean & AVG & $\mathbf{P}_{2}$ & P3 & $\mathbf{P 4}$ & P5 & P6 & P7 & P8 & AVG \\
\hline \multirow{6}{*}{99 percent } & 1 Year & $\mathrm{O}$ & 0 & 0 & $\mathrm{O}$ & 0 & 0 & 0 & 0 & 0.00 & 0 & 0 & $\mathrm{O}$ & 0 & 0 & 0 & 0 & $\frac{\mathbf{P}}{0.00}$ \\
\hline & 2 Years & 0 & 0 & 0 & 1 & 1 & 0 & 0 & 0 & 0.38 & 0 & 1 & 1 & 1 & 1 & 1 & 1 & 0.80 \\
\hline & 3 Years & 0 & 0 & 0 & 1 & 1 & 0 & 0 & 0 & 0.50 & 0 & 1 & 1 & 1 & 1 & 1 & 1 & 0.81 \\
\hline & 4 Years & 0 & 0 & 0 & 1 & 1 & 1 & 0 & 0 & 0.63 & 0 & 1 & 1 & 1 & 1 & 1 & 1 & 0.95 \\
\hline & 5 Years & 0 & 0 & 0 & 1 & 1 & 1 & 1 & 0 & 1.00 & 0 & 1 & 1 & 1 & 1 & 1 & 1 & 1.13 \\
\hline & 6 Years & 0 & 0 & 0 & 1 & 1 & 1 & 1 & 0 & 1.25 & 0 & 1 & 1 & 1 & 1 & 1 & 1 & 1.16 \\
\hline \multirow{6}{*}{95 percent } & 1 Year & 0 & 0 & 0 & 0 & 0 & 0 & 0 & 0 & 0.13 & 0 & 0 & 0 & 0 & 0 & 0 & 0 & 0.02 \\
\hline & 2 Years & 0 & 0 & 0 & 2 & 1 & 1 & 0 & 0 & 1.13 & 0 & 1 & 1 & 1 & 1 & 1 & 1 & 1.02 \\
\hline & 3 Years & 1 & 0 & 0 & 2 & 1 & 1 & 0 & 1 & 1.50 & 0 & 1 & 1 & 1 & 1 & 1 & 1 & 1.31 \\
\hline & 4. Years & 1 & 0 & 1 & 2 & 1 & 2 & 0 & 1 & 2.00 & 0 & 1 & 2 & 2 & 1 & 1 & 1 & 2.00 \\
\hline & 5 Years & 1 & 1 & 1 & 2 & 1 & 3 & 1 & 1 & 2.38 & 0 & 1 & 3 & 2 & 1 & 2 & 2 & 2.80 \\
\hline & 6 Years & 3 & 1 & 1 & 2 & 1 & 3 & 1 & 1 & 2.63 & 0 & 1 & 3 & 2 & 1 & 2 & 2 & 3.45 \\
\hline \multirow{6}{*}{90 percent } & 1 Year & 0 & 0 & 0 & 0 & 0 & 0 & 0 & 0 & 0.50 & 0 & 0 & 0 & 0 & 0 & 0 & 0 & 0.19 \\
\hline & 2 Years & 0 & 0 & 1 & 2 & 1 & 2 & 0 & 0 & 1.75 & 1 & 1 & 1 & 1 & 1 & 1 & 1 & 1.59 \\
\hline & 3 Years & 1 & 0 & 2 & 2 & 1 & 2 & 0 & 1 & 2.63 & 1 & 1 & 1 & 1 & 2 & 1 & 1 & 2.33 \\
\hline & 4. Years & 1 & 0 & 4 & 2 & 1 & 3 & 0 & 1 & 3.50 & 3 & 1 & 2 & 2 & 3 & 1 & 1 & 3.56 \\
\hline & 5 Years & 1 & 1 & 4 & 2 & 1 & 4 & 1 & 1 & 4.63 & 4 & 1 & 3 & 3 & 4 & 2 & 2 & 4.70 \\
\hline & 6 Years & 3 & 1 & 4 & 2 & 1 & 4 & 1 & 1 & 5.50 & 4 & 1 & 3 & 3 & 5 & 3 & 2 & 5.81 \\
\hline
\end{tabular}




\section{References}

Artzner, P., F. Delbaen, J.M. Eber and D. Heath, 1999. Coherent measures of risk. Mathematical Finance, 9(3): 203-228.

Baker, S., 2015. The financialization of storable commodities. McIntire School of Commerce University of Virginia Working Paper: 1-42.

Basak, S. and A. Pavlova, 2016. A model of financialization of commodities. The Journal of Finance, 71(4): 1511-1556.Available at: https://doi.org/10.1111/jofi.12408.

Basu, D. and J. Miffre, 2013. Capturing the risk premium of commodity futures: The role of hedging pressure. Journal of Banking \& Finance, 37(7): 2652-2664.Available at: https://doi.org/10.1016/j.jbankfin.2013.02.031.

Cabedo, J.D. and I. Moya, 2003. Estimating oil price 'value at risk'using the historical simulation approach. Energy Economics, 25(3): 239253.Available at: https://doi.org/10.1016/s0140-9883(02)00111-1.

Casassus, J. and C.P. Dufresne, 2005. Stochastic convenience yield implied from commodity futures and interest rates. The Journal of Finance, 60(5): 2283-2331.Available at: https://doi.org/10.1111/j.1540-6261.2005.00799.x.

Chen, Y.-H. and A.H. Tu, 2013. Estimating hedged portfolio value-at-risk using the conditional copula: An illustration of model risk. International Review of Economics \& Finance, 27: 514-528.Available at: https://doi.org/10.1016/j.iref.2013.01.006.

Chen, Y., W. Härdle and V. Spokoiny, 2007. Portfolio value at risk based on independent component analysis. Journal of Computational and Applied Mathematics, 205(1): 594-607.Available at: https://doi.org/10.1016/j.cam.2006.05.016.

Creti, A., M. Joëts and V. Mignon, 2013. On the links between stock and commodity markets' volatility. Energy Economics, 37: 1628.Available at: https://doi.org/10.1016/j.eneco.2013.01.005.

Danielsson, J., 2011. Financial risk forecasting. USA: John Wiley \& Sons, Inc

Daskalaki, C. and G. Skiadopoulos, 2011. Should investors include commodities in their portfolios after all? New evidence. Journal of Banking \& Finance, 35(10): 2606-2626.Available at: https://doi.org/10.1016/j.jbankfin.2011.02.022.

Edwards, F. and J. Liew, 1999. Managed commodity funds. The Journal of Futures Markets, 19(4): 377-411.Available at: https://doi.org/10.1002/(sici)1096-9934(199906)19:4<377::aid-fut1>3.0.co;2-3.

Ghorbel, A. and A. Trabelsi, 2014. Energy portfolio risk management using time-varying extreme value copula methods. Economic Modelling, 38: 470-485.Available at: https://doi.org/10.1016/j.econmod.2013.12.023.

Giot, P. and S. Laurent, 2003. Market risk in commodity markets: A VaR approach. Energy Economics, 25(5): 435-457.Available at: https://doi.org/10.1016/s0140-9883(03)00052-5.

Goh, J.W., K.G. Lim, M. Sim and W. Zhang, 2012. Portfolio value-at-risk optimization for asymmetrically distributed asset returns. European Journal of Operational Research, 221(2): 397-406.Available at: https://doi.org/10.1016/j.ejor.2012.03.012.

Hull, J., 2007. Risk management and financial institutions. USA: Prentice Hall.

Hung, J.-C., M.-C. Lee and H.-C. Liu, 2008. Estimation of value-at-risk for energy commodities via fat-tailed GARCH models. Energy Economics, 30(3): 1173-1 191.Available at: https://doi.org/10.1016/j.eneco.2007.11.004.

Irwin, S.H. and D.R. Sanders, 2011. Index funds, financialization, and commodity futures markets. Applied Economic Perspectives and Policy, 33(1): 1-31.Available at: https://doi.org/10.1093/aepp/ppq032.

Jacks, D., K. O'Rourke and J. Williamson, 2011. Commodity price volatility and world market integration since 1700. The Review of Economics and Statistics, 93(3): 800-813.Available at: https://doi.org/10.1162/rest_a_00091.

Jorion, P., 2007. Value-at-risk the new benchmark for managing financial risk. 3rd Edn., USA: McGraw-Hill Education.

Ledoit, O. and M. Wolf, 2008. Robust performance hypothesis testing with the sharpe ratio. Journal of Empirical Finance, 15(5): 850859.Available at: https://doi.org/10.1016/j.jempfin.2008.03.002.

Lin, P.-C. and P.-C. Ko, 2009. Portfolio value-at-risk forecasting with GA-based extreme value theory. Expert Systems with Applications, 36(2): 2503-2512.Available at: https://doi.org/10.1016/j.eswa.2008.01.086.

Markowitz, H., 1952. Portfolio selection. The Journal of Finance, 7(1): 77-91.

Nakaso, H., 2011. Report of the g-20 study group of commodities. G-20. November: 1-67. Available from https://www.cmegroup.com/education/files/G20Nakaso-November202011.pdf.

Narayan, P.K., S. Narayan and S.S. Sharma, 2013. An analysis of commodity markets: What gain for investors? Journal of Banking \& Finance, 37(10): 3878-3889.Available at: https://doi.org/10.1016/j.jbankfin.2013.07.009.

Palomba, G. and L. Riccetti, 2012. Portfolio frontiers with restrictions to tracking error volatility and value at risk. Journal of Banking \& Finance, 36(9): 2604-2615.Available at: https://doi.org/10.1016/j.jbankfin.2012.05.014.

Plantier, L., 2012. Commodity markets and commodity mutual funds. ICI Research Perspective, 18(3): 1-32.

Rossi, B., 2012. The changing relationship between commodity prices and equity prices in commodity exporting countries. IMF Economic Review, 60(4): 533-569.

Routledge, B.R., D.J. Seppi and C.S. Spatt, 2000. Equilibrium forward curves for commodities. The Journal of Finance, 55(3): 12971338.Available at: https://doi.org/10.1111/0022-1082.00248.

Siburg, K.F., P. Stoimenov and G.N. Weiß, 2015. Forecasting portfolio-value-at-risk with nonparametric lower tail dependence estimates. Journal of Banking \& Finance, 54: 129-140.Available at: https://doi.org/10.1016/j.jbankfin.2015.01.012.

Stoll, H. and R. Whaley, 2010. Commodity index investing and commodity futures prices. Journal of Applied Finance, 20(1): 7-46.

Tang, K. and W. Xiong, 2012. Index investment and the financialization of commodities. Financial Analysts Journal, 68(6): 54-74.Available at: https://doi.org/10.2469/faj.v68.n6.5.

Vivian, A. and M.E. Wohar, 2012. Commodity volatility breaks. Journal of International Financial Markets, Institutions and Money, 22(2): 395-422.

You, L. and R.T. Daigler, 2013. AM arkowitz optimization of commodity futures portfolios. Journal of Futures Markets, 33(4): 343368.Available at: https://doi.org/10.1002/fut.2 1553 .

Citation | Rangga Handika; Mahjus Ekananda (2019). Benefits and Consequences of Diversification: Evidence from Financialzed Commodity Portfolios. Asian Business Research Journal, 4: 17-28. History:

Received: 5 June 2019

Revised: 8 July 2019

Accepted: 12 August 2019

Published: 3 September 2019

Published: 3 September 2019
Licensed: This work is licensed under a Creative Commons

Attribution 3.0 License (oc)

Publisher: Eastern Centre of Science and Education
Acknowledgement: Both authors contributed to the conception and design of Acknowled

Funding: This study received no specific financial support

Competing Interests: The authors declare that they have no conflict of interests.

Transparency: The authors confirm that the manuscript is an honest, accurate, and transparent account of the study was reported; that no vital features of the study have been omitted; and that any discrepancies from the study as planned have been explained. study as planned have been explained.
Ethical: This study follows all ethical practices during writing.

Eastern Centre of Science and Education is not responsible or answerable for any loss, damage or liability, etc. caused in relation to/arising out of the use of the content. Any queries should be directed to the corresponding author of the article. 